\title{
Novel GRP78 Molecular Chaperone Expression Down-regulators JBIR-04 and -05 Isolated from Streptomyces violaceoniger
}

\author{
Miho Izumikawa, Jun-ya Ueda, Shuhei Chijiwa, Motoki Takagi, Kazuo Shin-ya
}

Received: July 18, 2007 / Accepted: September 14, 2007

(C) Japan Antibiotics Research Association

\begin{abstract}
In the course of our screening program for regulators of the expression of GRP78 molecular chaperone, JBIR-04 (1) and -05 (2) were isolated from Streptomyces violaceoniger 4541-SVS3 as congeners of prunustatin A (3). The structures of 1 and 2 were determined by the analyses of the spectroscopic data. These compounds mainly consist of an amino acid and amino acid derived $\alpha$-hydroxy acid residues. $\mathbf{1}$ and $\mathbf{2}$ inhibited the expression of GRP78 induced by 2-deoxyglucose in human fibrosarcoma HT1080 cells, but their activities were highly reduced compared with those of $\mathbf{3}$ and SW-163A.
\end{abstract}

Keywords JBIR-04 and -05, Streptomyces violaceoniger, neoantimycin, prunustatin A, SW-163A, molecular chaperone, GRP78

GRP78 acts as a molecular chaperone in the endoplasmic reticulum (ER) to promote protein folding. The enhancement of the ER stress response has been proven to play a role in mechanisms of resistance to chemotherapy and hypoglycemic stress in solid tumors [1], while the reduction of the ER stress response is involved in the pathology of central nervous diseases such as Alzheimer's and Parkinson's diseases [2]. The ER stress response causes an increase in gene expression of a number of ER chaperones such as GRP78/Bip and GRP94 [3]. In the course of our screening program for regulators of GRP78 molecular chaperone expression, we have isolated versipelostatin [4], a new member of neoantimycin [5] family, prunustatin A (3) [6], and SW-163A (4) [7]. Further searching for congeners from the prunustatin A-producing strain resulted in the isolation of JBIR-04 (1) and -05 (2). In this paper, we report herein the isolation, structure elucidation and brief structure-activity correlations of $\mathbf{1}$ and 2 .

The prunustatin-producing strain $S$. violaceoniger 4541 SVS3 was cultured at $27^{\circ} \mathrm{C}$ for 5 days in $500-\mathrm{ml}$ Erlenmeyer flasks containing a medium consisting of $2.5 \%$ starch, $1.5 \%$ soy bean meal, $0.2 \%$ dry yeast and $0.4 \%$ $\mathrm{CaCO}_{3}$ (pH 6.2 before sterilization). The collected mycelial cake from fermented whole broth (2 liters) was extracted with $\mathrm{Me}_{2} \mathrm{CO}(400 \mathrm{ml})$. The extract was evaporated in vacuo, and the residual aqueous concentrate was extracted with EtOAc $(150 \mathrm{ml} \times 3)$. The organic layer residue $(0.36 \mathrm{~g})$ was separated on a silica gel flash column (Purif-Pack SI60, Moritex) with a $n$-hexane-EtOAc linear gradient system $(0 \sim 100 \%$ EtOAc). The $50 \sim 100 \%$ EtOAc eluate was further purified by preparative HPLC using PEGASILODS (Senshu Pak, 20 i.d. $\times 150 \mathrm{~mm}$ ) developed with $85 \%$ aqueous acetonitrile to give $\mathbf{1}$ (1.1 $\mathrm{mg}$, Rt 9.0 minutes) and 2 (2.63 mg, Rt 8.5 minutes).

The physico-chemical properties of $\mathbf{1}$ and $\mathbf{2}$ are summarized in Table 1. $\mathbf{1}$ and $\mathbf{2}$ were isolated as colorless amorphous and pale yellow amorphous solids, respectively. The molecular formulas of $\mathbf{1}$ and $\mathbf{2}$ were established as $\mathrm{C}_{33} \mathrm{H}_{39} \mathrm{NO}_{10}$ and $\mathrm{C}_{33} \mathrm{H}_{42} \mathrm{~N}_{2} \mathrm{O}_{11}$, respectively, on the basis of HR-ESI-MS analysis.

The tabulated ${ }^{13} \mathrm{C}$ - and ${ }^{1} \mathrm{H}-\mathrm{NMR}$ spectral data for $\mathbf{1}$ and $\mathbf{2}$
K. Shin-ya (Corresponding author): Biological Information Research Center (BIRC), National Institute of Advanced Industrial Science and Technology (AIST), 2-42 Aomi, Koto-ku, Tokyo 135-0064, Japan, E-mail: k-shinya@aist.go.jp
M. Takagi (Corresponding author), M, Izumikawa, J. Ueda, S. Chijiwa: Japan Biological Information Research Center (JBIRC), Japan Biological Informatics Consortium (JBIC), 2-42 Aomi, Koto-ku, Tokyo 135-0064, Japan, E-mail: motoki-takagi@aist.go.jp 

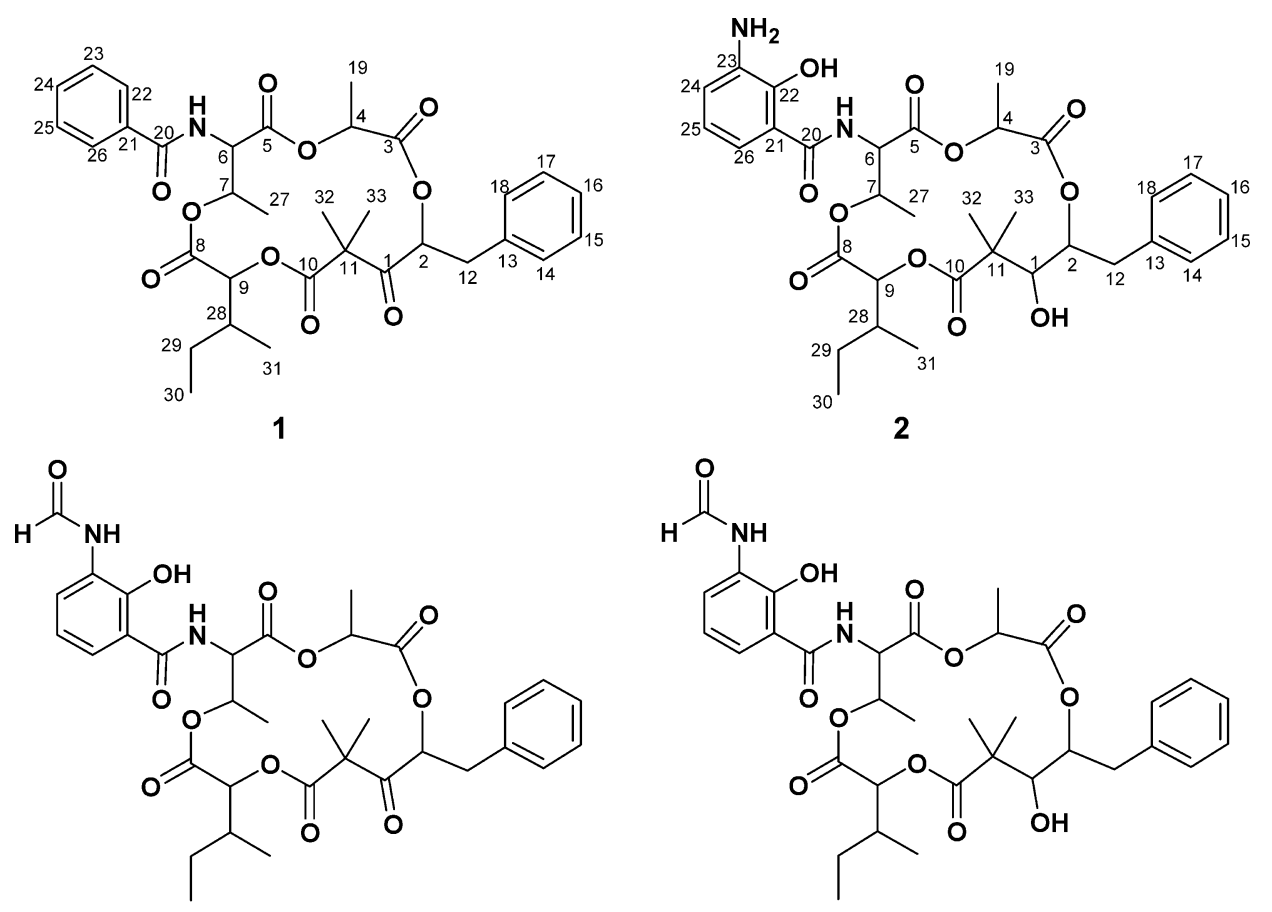

3

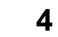

Fig. 1 Structures of JBIR-04 (1), JBIR-05 (2), prunustatin A (3) and SW-163A (4).

Table 1 Physico-chemical properties of JBIR-04 (1) and -05 (2)

\begin{tabular}{|c|c|c|}
\hline & 1 & 2 \\
\hline Appearance & Colorless amorphous solid & Pale yellow amorphous solid \\
\hline Melting point & $60 \sim 62^{\circ} \mathrm{C}$ & $104 \sim 107^{\circ} \mathrm{C}$ \\
\hline$[\alpha]_{D}^{22}(\mathrm{MeOH})$ & $-28.6^{\circ}(c 0.01)$ & $-17.3^{\circ}(c 0.03)$ \\
\hline Molecular formula & $\mathrm{C}_{33} \mathrm{H}_{39} \mathrm{NO}_{10}$ & $\mathrm{C}_{33} \mathrm{H}_{42} \mathrm{~N}_{2} \mathrm{O}_{11}$ \\
\hline \multicolumn{3}{|l|}{ HR-ESI-MS (m/z) } \\
\hline found: & $610.2664[\mathrm{M}+\mathrm{H}]^{+}$ & $643.2887[\mathrm{M}+\mathrm{H}]^{+}$ \\
\hline calcd: & 610.2652 & 643.2867 \\
\hline UV $\lambda_{\max }(\mathrm{MeOH}) \mathrm{nm}(\varepsilon)$ & $219(10,000)$ & $228(37,300), 337(5,800)$ \\
\hline IR $v_{\max }\left(\mathrm{CHCl}_{3}\right) \mathrm{cm}^{-1}$ & $1750,1720,1670$ & $3550,3440,1750,1715,1645$ \\
\hline
\end{tabular}

are shown in Table 2. The IR spectrum of $\mathbf{1}$ showed absorption of ester $\left(v_{\max } 1750\right.$ and $\left.1720 \mathrm{~cm}^{-1}\right)$ and amide $\left(1670 \mathrm{~cm}^{-1}\right)$ groups. The direct connectivity of protons and carbons were established by the HSQC spectrum. The ${ }^{1} \mathrm{H}-$ ${ }^{1} \mathrm{H}$ COSY and HMBC spectra established five partial structures (Fig. 2). The proton-proton correlations observed in the ${ }^{1} \mathrm{H}-{ }^{1} \mathrm{H}$ COSY include $14,18-\mathrm{H}\left(\delta_{\mathrm{H}} 7.32\right)$, $15,17-\mathrm{H}\left(\delta_{\mathrm{H}} 7.32\right)$ and $16-\mathrm{H}\left(\delta_{\mathrm{H}} 7.25\right)$, revealing the presence of a benzene ring moiety. The ${ }^{1} \mathrm{H}-{ }^{1} \mathrm{H}$ couplings between an oxymethine proton $2-\mathrm{H}\left(\delta_{\mathrm{H}} 5.784, \delta_{\mathrm{C}} 79.1\right)$ and methylene protons $12-\mathrm{H}\left(\delta_{\mathrm{H}} 3.40,3.15\right)$, together with ${ }^{1} \mathrm{H}-$ ${ }^{13} \mathrm{C}$ long-range couplings in $\mathrm{HMBC}$ spectrum from $2-\mathrm{H}$,
$12-\mathrm{H}$ and $15,17-\mathrm{H}$ to $\mathrm{C}-13\left(\delta_{\mathrm{C}} 136.6\right)$ and $14,18-\mathrm{H}$ to $\mathrm{C}-12$ $\left(\delta_{\mathrm{C}} 37.7\right)$ established a phenethyl residue. The protons of two singlet methyl groups $32-\mathrm{H}\left(\delta_{\mathrm{H}} 1.42\right)$ and $33-\mathrm{H}\left(\delta_{\mathrm{H}}\right.$ $1.25)$ were each long-range coupled to an ester carbonyl carbon $\mathrm{C}-10\left(\delta_{\mathrm{C}} 171.6\right)$, a quaternary carbon $\mathrm{C}-11\left(\delta_{\mathrm{C}}\right.$ 54.0) and a ketone carbonyl carbon $\mathrm{C}-1\left(\delta_{\mathrm{C}} 203.7\right)$, which in turn were coupled to 2-H. These HMBC correlations indicated the successive connectivity of C-2, C-1 and C-11 as shown in Fig. 2. Thus, a 4-hydroxy-2,2-dimethyl-3-oxo5-phenylpentanoic acid moiety was elucidated as a partial structure of $\mathbf{1}$ as shown in Fig. 2. A 2-hydroxypropionic acid moiety was established by ${ }^{1} \mathrm{H}-{ }^{1} \mathrm{H}$ correlation between 
Table $2{ }^{13} \mathrm{C}(150 \mathrm{MHz})$ - and ${ }^{1} \mathrm{H}(600 \mathrm{MHz})-\mathrm{NMR}$ data for $\mathbf{1}$ and $\mathbf{2}$ in $\mathrm{CDCl}_{3}$

\begin{tabular}{|c|c|c|c|c|}
\hline & \multicolumn{2}{|r|}{1} & \multicolumn{2}{|r|}{2} \\
\hline & $\delta_{\mathrm{C}}$ & $\delta_{\mathrm{H}}$ & $\delta_{\mathrm{C}}$ & $\delta_{\mathrm{H}}$ \\
\hline 1 & 203.7 & & 79.2 & $3.20(d, 11.7)$ \\
\hline 2 & 79.1 & $5.784(\mathrm{dd}, 10.9,2.9)$ & 72.2 & $5.48(d d, 9.7,5.6)$ \\
\hline 3 & 169.1 & & 170.0 & \\
\hline 4 & 69.9 & $5.33(q, 6.8)$ & 69.1 & $5.47(q, 7.0)$ \\
\hline 5 & 168.6 & & 168.2 & \\
\hline 6 & 56.1 & $5.21(\mathrm{dd}, 9.1,2.9)$ & 55.4 & $5.10(\mathrm{dd}, 8.8,2.1)$ \\
\hline 7 & 72.1 & $5.777(\mathrm{dq}, 2.9,6.8)$ & 72.4 & $5.72(d q, 2.1,6.5)$ \\
\hline 8 & 168.7 & & 168.3 & \\
\hline 9 & 75.9 & $5.05(d, 9.4)$ & 75.4 & $4.67(d, 8.5)$ \\
\hline 10 & 171.6 & & 177.2 & \\
\hline 11 & 54.0 & & 45.5 & \\
\hline \multirow[t]{2}{*}{12} & 37.7 & $3.40(\mathrm{dd}, 14.5,2.9)$ & 40.0 & $3.17(d d, 14.1,5.6)$ \\
\hline & & $3.15(\mathrm{dd}, 14.5,10.9)$ & & $2.93(d d, 14.1,9.7)$ \\
\hline 13 & 136.6 & & 136.97 & \\
\hline 14,18 & 129.7 & $7.32(\mathrm{~m})$ & 129.4 & $7.20(d, 7.9)$ \\
\hline 15,17 & 128.7 & $7.32(\mathrm{~m})$ & 128.8 & $7.27(t, 7.9)$ \\
\hline 16 & 127.2 & $7.25(\mathrm{~m})$ & 127.0 & $7.20(\mathrm{~m})$ \\
\hline 19 & 16.7 & $1.26(d, 6.8)$ & 17.4 & $1.00(d, 7.0)$ \\
\hline 20 & 168.2 & & 171.0 & \\
\hline 21 & 133.6 & & 113.0 & \\
\hline 22 & 127.5 & $7.91(d, 7.3)$ & 149.9 & \\
\hline 23 & 129.0 & $7.51(t, 7.6)$ & 137.02 & \\
\hline 24 & 132.5 & $7.58(t, 7.6)$ & 118.7 & $6.86(d, 7.6)$ \\
\hline 25 & 129.0 & $7.51(t, 7.6)$ & 119.1 & $6.75(t, 7.9)$ \\
\hline 26 & 127.5 & $7.91(d, 7.3)$ & 114.8 & $6.96(d, 7.9)$ \\
\hline 27 & 16.6 & $1.41(d, 6.8)$ & 16.6 & $1.32(d, 6.5)$ \\
\hline 28 & 36.4 & $2.03(\mathrm{~m})$ & 36.2 & $1.96(\mathrm{~m})$ \\
\hline \multirow[t]{2}{*}{29} & 24.6 & 1.51 (m) & 24.9 & $1.52(\mathrm{~m})$ \\
\hline & & $1.17(\mathrm{~m})$ & & $1.20(\mathrm{~m})$ \\
\hline 30 & 10.5 & $0.89(t, 7.8)$ & 10.7 & $0.88(t, 7.2)$ \\
\hline 31 & 14.2 & $0.90(d, 7.6)$ & 14.5 & $0.89(d, 6.8)$ \\
\hline 32 & 22.7 & $1.42(\mathrm{~s})$ & 27.2 & $1.42(\mathrm{~s})$ \\
\hline 33 & 20.8 & 1.25 (s) & 22.0 & $1.32(\mathrm{~s})$ \\
\hline $1-\mathrm{OH}$ & & & & $3.63(d, 11.7)$ \\
\hline 6-NH & & $6.95(d, 9.1)$ & & $7.03(d, 8.8)$ \\
\hline $22-\mathrm{OH}$ & & & & 12.03 (br.s) \\
\hline
\end{tabular}

an oxymethine proton $4-\mathrm{H}\left(\delta_{\mathrm{H}} 5.33, \delta_{\mathrm{C}} 69.9\right)$ and a methyl proton $19-\mathrm{H}\left(\delta_{\mathrm{H}} 1.26\right)$, and ${ }^{1} \mathrm{H}-{ }^{13} \mathrm{C}$ long-range correlations between $19-\mathrm{H}$ and an ester carbonyl carbon C-3 $\left(\delta_{\mathrm{C}} 169.1\right)$. The coupling between $9-\mathrm{H}\left(\delta_{\mathrm{H}} 5.05\right)$ and a carbonyl carbon C-8 $\left(\delta_{\mathrm{C}} 168.7\right)$, along with the sequence from $9-\mathrm{H}$ to $30-\mathrm{H}$ $\left(\delta_{\mathrm{H}} 0.89\right)$ through $28-\mathrm{H}\left(\delta_{\mathrm{H}} 2.03\right)$, which was additionally coupled to a methyl proton $31-\mathrm{H}\left(\delta_{\mathrm{H}} 0.90\right)$, and $29-\mathrm{H}\left(\delta_{\mathrm{H}}\right.$ $1.51,1.17)$ observed in the ${ }^{1} \mathrm{H}-{ }^{1} \mathrm{H}$ COSY spectrum of 1 established a 2-hydroxy-3-methylpentanoic acid moiety as shown in Fig. 2. The sequence from an amide proton 6-NH $\left(\delta_{\mathrm{H}} 6.95\right)$ to a methyl proton $27-\mathrm{H}\left(\delta_{\mathrm{H}} 1.41\right)$ through an $\alpha$ methine proton $6-\mathrm{H}\left(\delta_{\mathrm{H}} 5.21, \delta_{\mathrm{C}} 56.1\right)$ and an oxymethine proton $7-\mathrm{H}\left(\delta_{\mathrm{H}} 5.777\right)$ was revealed. In addition to these correlations, a long-range coupling from the methine proton $6-\mathrm{H}$ to an ester carbonyl carbon $\mathrm{C}-5\left(\delta_{\mathrm{C}} 168.6\right)$ was observed. These results indicated the presence of a threonine residue. The proton-proton correlations observed in the COSY among $22,26-\mathrm{H}\left(\delta_{\mathrm{H}} 7.91\right), 23,25-\mathrm{H}\left(\delta_{\mathrm{H}} 7.51\right)$ 


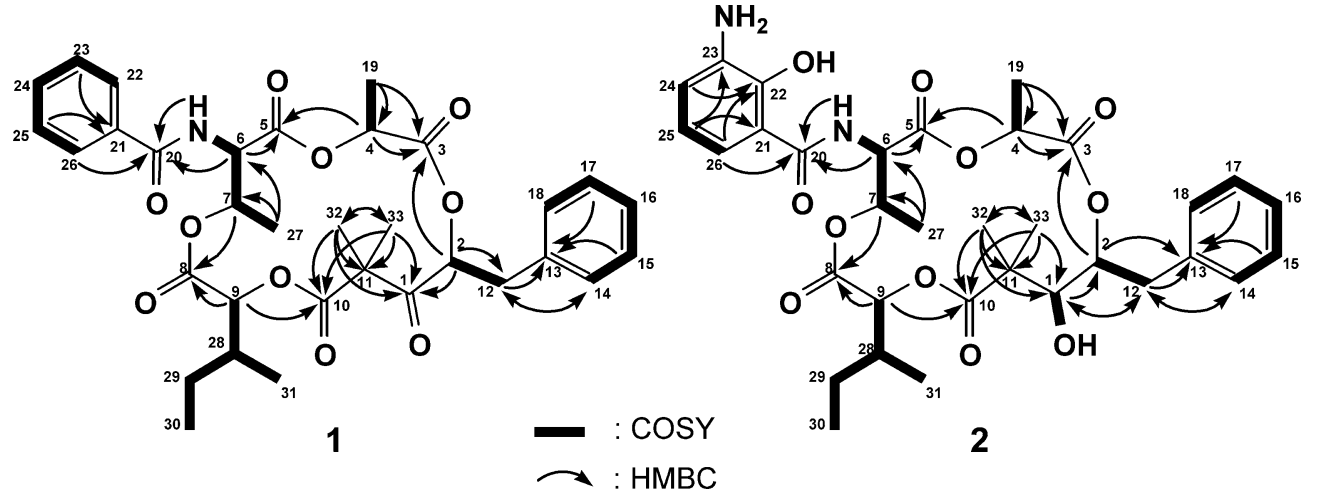

Fig. 2 Key correlations in 2D NMR of $\mathbf{1}$ and $\mathbf{2}$.

and $24-\mathrm{H}\left(\delta_{\mathrm{H}} 7.58\right)$ revealed the presence of a benzene ring moiety. The ${ }^{1} \mathrm{H}-{ }^{13} \mathrm{C}$ long-range couplings between $23,25-\mathrm{H}$ and an aromatic quaternary carbon $\mathrm{C}-21\left(\delta_{\mathrm{C}} 133.6\right), 22,26-$ $\mathrm{H}$ and an amide carbonyl carbon $\mathrm{C}-20\left(\delta_{\mathrm{C}} 168.2\right)$ revealed a benzoic acid moiety. The connectivity of these partial structures was elucidated by the ${ }^{1} \mathrm{H}-{ }^{13} \mathrm{C}$ long-range couplings between $2-\mathrm{H}$ and $\mathrm{C}-3,4-\mathrm{H}$ and $\mathrm{C}-5,6-\mathrm{H}$ and $\mathrm{C}-$ 20, 7-H and $\mathrm{C}-8$, and 9-H and $\mathrm{C}-10$. In this manner, the structure of $\mathbf{1}$ was determined as shown in Fig. 1.

The IR spectrum of $\mathbf{2}$ showed presence of the hydroxyl $\left(3550 \mathrm{~cm}^{-1}\right)$ and amine $\left(3440 \mathrm{~cm}^{-1}\right)$ functions in addition to the ester $\left(v_{\max } 1750\right.$ and $\left.1715 \mathrm{~cm}^{-1}\right)$ and amide $\left(1645 \mathrm{~cm}^{-1}\right)$ groups which were also observed in $\mathbf{1}$. UV absorption at $337 \mathrm{~nm}$ suggested the presence of a salicylate moiety as a chromophore in $\mathbf{2}$ [5 8]. As observed in $\mathbf{1}, \mathbf{2}$ also consists of an amino acid and amino acid derived $\alpha$-hydroxy acid residues, in which the lactic acid, the 2-hydroxy-3-methylpentanoic acid, and the threonine moieties are common between $\mathbf{1}$ and $\mathbf{2}$ as shown in Fig. 2. The 4-hydroxy-2,2-dimethyl-3-oxo-5-phenylpentanoic acid and benzoic acid moieties in $\mathbf{1}$ were replaced by 3,4dihydroxy-2,2-dimethyl-5-phenylpentanoic acid and 3amino-2-hydroxybenzoic acid moieties in $\mathbf{2}$, demonstrated as follows. In the ${ }^{1} \mathrm{H}-{ }^{1} \mathrm{H}$ COSY spectrum of 2 , the spin couplings between a hydroxyl proton 1-OH $\left(\delta_{\mathrm{H}} 3.63\right)$ and an oxymethine proton $1-\mathrm{H}\left(\delta_{\mathrm{H}} 3.20, \delta_{\mathrm{C}} 79.2\right)$, and between another oxymethine proton $2-\mathrm{H}\left(\delta_{\mathrm{H}} 5.48, \delta_{\mathrm{C}} 72.2\right)$ and methylene protons $12-\mathrm{H}\left(\delta_{\mathrm{H}} 3.17,2.93\right)$ were observed. In the same manner as observed in $\mathbf{1}$, the presence of a benzene ring moiety was also revealed in $\mathbf{2}$ as shown in Fig. 2. In the $\mathrm{HMBC}$ spectrum, ${ }^{1} \mathrm{H}-{ }^{13} \mathrm{C}$ long-range couplings from $1-\mathrm{H}$ to $\mathrm{C}-2$ and $\mathrm{C}-12\left(\delta_{\mathrm{C}} 40.0\right)$, and from $12-\mathrm{H}$ to an aromatic carbon $\mathrm{C}-13\left(\delta_{\mathrm{C}} 136.97\right)$, which in turn long-range coupled to aromatic protons $15,17-\mathrm{H}\left(\delta_{\mathrm{H}}\right.$ 7.27), established a 3-phenyl-propane-1,2-diol moiety. In addition, ${ }^{1} \mathrm{H}-{ }^{13} \mathrm{C}$ long-range couplings were observed from two singlet methyl groups $32-\mathrm{H}\left(\delta_{\mathrm{H}} 1.42\right)$ and $33-\mathrm{H}$ $\left(\delta_{\mathrm{H}} 1.32\right)$ to an ester carbonyl carbon $\mathrm{C}-10\left(\delta_{\mathrm{C}} 177.2\right)$, a quaternary carbon $\mathrm{C}-11 \quad\left(\delta_{\mathrm{C}} 45.5\right)$ and oximethine carbon C-1. Thus, the 3,4-dihydroxy-2,2-dimethyl-5phenylpentanoic acid moiety was elucidated as a partial structure of $\mathbf{2}$ as shown in Fig. 2. The connectivity of these partial structures was elucidated by the ${ }^{1} \mathrm{H}-{ }^{13} \mathrm{C}$ long-range couplings between 2-H and C-3, 4-H and C-5, 7-H and C-8, and 9-H and $\mathrm{C}-10$, which gave a macrocyclic structure of $\mathbf{2}$ (Fig. 2). The proton spin couplings among aromatic protons $24-\mathrm{H}\left(\delta_{\mathrm{H}} 6.86\right), 25-\mathrm{H}\left(\delta_{\mathrm{H}} 6.75\right)$ and $26-\mathrm{H}\left(\delta_{\mathrm{H}} 6.96\right)$ indicated a 1,2,3-trisubstituted benzene ring moiety. The aromatic proton $26-\mathrm{H}$ was long-range coupled to a carbonyl carbon C-20 ( $\left.\delta_{\mathrm{C}} 171.0\right)$ at the peri position, which indicated that this carbonyl carbon was substituted at C-21. ${ }^{1} \mathrm{H}-{ }^{13} \mathrm{C}$ long-range couplings were observed from $25-\mathrm{H}$ to quaternary aromatic carbons that possessed chemical shifts at $\delta_{\mathrm{C}} 113.0$ and $\delta_{\mathrm{C}} 137.02$. From the substituent at C-21, these carbon signals should be assigned to $\mathrm{C}-21\left(\delta_{\mathrm{C}} 113.0\right)$ and $\mathrm{C}-23\left(\delta_{\mathrm{C}} 137.02\right)$, respectively. The aromatic protons $24-\mathrm{H}$ and $26-\mathrm{H}$ were long-range coupled to $\mathrm{C}-22\left(\delta_{\mathrm{C}}\right.$ 149.9). By taking into consideration the ${ }^{13} \mathrm{C}$ chemical shifts of these aromatic carbons and molecular formula of $\mathbf{2}$, a hydroxyl and an amine residue should be substituted at positions C-22 and C-23, respectively. Thus, the remaining unit of $\mathbf{2}$ was revealed to be the 3-amino-2-hydroxybenzoic acid moiety. The connectivity between the macrocyclic substructure and the 3-amino-2-hydroxybenzoic acid moiety was determined by the ${ }^{1} \mathrm{H}-{ }^{13} \mathrm{C}$ long-range couplings between $6-\mathrm{NH}\left(\delta_{\mathrm{H}} 7.03\right), 6-\mathrm{H}\left(\delta_{\mathrm{H}} 5.10\right)$ and $\mathrm{C}-20$.

The structure of $\mathbf{1}$ resembled that of $\mathbf{3}$, but contained of the non-substituted benzoate residue instead of the 3-(formylamino)-salicylate moiety. The structure of $\mathbf{2}$ resembled that of $\mathbf{4}$, lacking only a formyl residue. The $\mathbf{3 -}$ (formylamino)-salicylate substructure is the representative functional moiety in the antimycin family, which exhibits 
antirespiratory and antioxidative activities [8]. Thus, these compounds are extremely useful tools for identifying antirespiratory activity.

Human fibrosarcoma cell line HT1080 cells that were transformed with the luciferase reporter gene under the regulation of the GRP78 promoter produced luciferase in four fold greater quantity than did the control when treated with $10 \mathrm{mM}$ of 2-deoxyglucose. In this evaluation system, 1 and 2 reduced the expression of the reporter gene with $\mathrm{IC}_{50}$ values of 2407 and $282 \mathrm{nM}$, respectively. In the same manner, the structurally related compounds 3 and 4 exhibited inhibitory activity in this assay with $\mathrm{IC}_{50}$ values of 12 and $23 \mathrm{nM}$, respectively. Since the activity of 2 was 12 times less than that of $\mathbf{4}$ and $\mathbf{1}$ was 200 fold less than $\mathbf{3}$, the hydroxyl and formylamino residues on the benzene ring play an important role in enhancing the inhibitory effect against GRP78 expression induced by 2-deoxyglucose. These results suggested that an antirespiratory effect is not the mode of action of these compounds. Although the mode of action of versipelostatin was investigated in detail [9], its target is still unknown. Clarifying the target of these compounds is expected to result in elucidating novel and undiscovered pathways of GRP78 expression.

Acknowledgements This work was supported by the grant from the New Energy and Industrial Technology Development Organization (NEDO) of Japan.

\section{References}

1. Katschinski DM, Jacobson EL, Wiedemann GJ, Robins HI.
Modulation of VP-16 cytotoxicity by carboplatin and $41.8^{\circ} \mathrm{C}$ hyperthermia. J Cancer Res Clin Oncol 127: 425-435 (2001)

2. Imaizumi K, Miyoshi K, Katayama T, Yoneda T, Taniguchi M, Kubo T, Tohyama M. The unfolded protein response and Alzheimer's disease. Biochem Biophys Acta 1536: 85-96 (2001)

3. Kaufman RJ. Stress signaling from the lumen of the endoplasmic reticulum: coordination of gene transcriptional and translational controls. Genes Dev 13: 1211-1233 (1999)

4. Park HR, Furihata K, Hayakawa Y, Shin-ya K. Versipelostatin, a novel GRP/Bip molecular chaperone down-regulator of microbial origin. Tetrahedron Lett 43: 6941-6945 (2002)

5. Caglioti L, Misiti D, Mondelli R, Selva A, Arcamone F, Cassinelli G. The structure of neomycin. Tetrahedron 25: 2193-2221 (1969)

6. Umeda Y, Chijiwa S, Furihata K, Furihata K, Sakuda S, Nagasawa H, Watanabe H, Shin-ya K. Prunustatin A, a novel GRP78 molecular chaperone down-regulator isolated form Streptomyces violaceoniger. J Antibiot 58: 206-209 (2005)

7. Takahashi K, Tsuda E, Kurosawa K. SW-163A and B, novel immunosuppressants produced by Streptomyces sp. J Antibiot 54: 867-873 (2001)

8. Kinoshita M, Wada M, Umezawa S. The total syntheses of a diastereomeric mixture of antimycin $\mathrm{A}_{3}$ (blastmycin). J Antibiot 22: 580-582 (1969)

9. Park H-R, Tomida A, Sato S, Tsukumo Y, Yun J, Yamori T, Hayakawa Y, Tsuruo T, Shin-ya K. Blockade of survival response to glucose deprivation for selective killing of tumor cells. J Natl Can Inst 96: 1300-1330 (2004) 